\section{THE ELDERLY AMPUTEE}

\author{
BY \\ D. S. McKENZIE, M.B., Ch.B. \\ (From the Ministry of Pensions Limb Fitting Centre, \\ Roehampton)
}

Since the advent of the National Health Service the Ministry of Pensions Limb Service has been called upon to treat large numbers of elderly patients, and it was therefore felt that a more detailed study of the results obtained by current methods would be of value and perhaps form a guide to the minutiae of technique and selection in future.

At the inception of the N.H.S. the experience of the Limb Service in the rehabilitation of elderly patients was not extensive, the technique of rehabilitation having been evolved primarily in relation to active ex-Service men. This technique had, however, met with success, and we were encouraged to adopt the same methods, modified only in so far as the programme was adapted to the physical capacity of the higher age groups and the more enfeebled.

Enough time has now elapsed to assess results in respect of the first 6,000 N.H.S. patients accepted for prosthetic treatment at Roehampton. Of these, 344 were "primary" cases-that is, patients who had not yet worn a prosthesis-aged 65 or more, representing some $30 \%$ of all the primary lower-limb cases received during the same period. It has been estimated that 4,000 to 5,000 major amputations are performed each year in the British Isles in times of peace, so that the Limb Service can expect some 1,350 new elderly patients annually. The wastage from death and intercurrent disease is, of course, considerable, and only a proportion are successfully equipped with prostheses; but elderly patients requiring continued supervision by the Limb Service throughout the years cannot be expected to be less than 5,000 to 6,000 at any given time.

\section{Technique}

The technique adopted in the treatment of this age group has followed the same general plan as that used in the past. Patients are seen as out-patients in the limb centre as soon as possible after reference from hospital. There seems to be no general decision concerning the stage at which patients should be referred. Some hospitals like their cases to be seen by the limb surgeon at an early stage, while others wait until the patient has been discharged to his home.

At first the limb surgeon makes a local and general examination and assesses the capabilities. If further stump or general treatment is indicated he will normally refer the patient back to his hospital with suitable recommendations, unless he feels that the special experience of the Roehampton staff is required. At the earliest possible stage a pylon is ordered for thigh cases, while below-knee cases normally are fitted direct with the permanent prosthesis. The pylons now used are provided with "durestos" sockets (Scales, 1950), and are very light. They can be made in a very short time, and rehabilitation can begin at an early date and so promote morale. It is found that many patients referred to this centre have not persisted with stump exercises and bandaging, the details of which technique have been published by the Ministry of Pensions (1951). Omission of this treatment, or failure to persist in it, results in a flabby stump with terminal oedema and general debility with lack of muscular tone, and in delays and difficulties in limb-training which are in some cases insuperable.
Training in walking is started as soon as possible after delivery of the pylon. We find it better for morale if this is carried out by daily attendances on an out-patient basis, and only those who have too far to travel or have complicating factors are admitted to the hospital. The training consists of individual balancing and walking exercises between handrails, progressing to walking with sticks, stairclimbing, walking on slopes and cambers, etc., and instruction in meeting all the ordinary needs of existence. In conjunction with this, group therapy is employed in the form of suitably modified remedial exercises designed to promote general improvement in muscle tone, to improve reactions, and to stimulate morale. The training is continued until the patient is fully independent or until no further progress can be made. Thus the single belowknee amputee may have two weeks' and the double-thigh subject four or more weeks' training.

After training, the patient is kept under observation by a follow-up, and the permanent prosthesis is prescribed when function merits it. Further training is given after delivery of the permanent prosthesis.

\section{Results}

An attempt has been made to assess results obtained in the 344 cases under review in relation to the age and sex of the patient, the site of amputation, the cause of amputation, and the presence or absence of complications. Rehabilitation was regarded as successful in $171(49.7 \%)$. No very exacting criteria have been taken, but cases were considered to be successful if appreciable and regular daily use has been made of the prosthesis for a period of not less than six months from completion of fitting and instruction. Failure occurred in 101 cases $(29.4 \%)$. Death supervened during rehabilitation procedures or within six months of completion in 31 cases $(9 \%)$. Fitting was not attempted in 16 cases $(4.6 \%)$, the result remains uncertain in 5 cases $(1.5 \%)$, and follow-up has failed to trace 20 patients $(5.8 \%)$.

Table I.-Results in Relation to Age

\begin{tabular}{|c|c|c|c|c|c|c|}
\hline Age: & $85+$ & $80-4$ & $75-9$ & $70-4$ & $65-9$ & Total \\
\hline $\begin{array}{ll}\mathbf{S} & . . \\
\text { F } & . . \\
\text { D } & . . \\
\text { NT } & . \\
\text { NA } \\
\text { U } & . .\end{array}$ & $\begin{array}{c}3 \\
(50 \%) \\
2 \% \\
(33.3 \%) \\
0 \\
0 \\
1 \\
(16.7 \%) \\
0\end{array}$ & $\begin{array}{c}7 \\
(29.3 \%) \\
9 \\
(37.5 \%) \\
2 \%) \\
(8 \cdot 3 \%) \\
2 \% \\
(8.3 \%) \\
2 \% \\
(8.3 \%) \\
2 \% \\
(8.3 \%)\end{array}$ & $\begin{array}{c}31 \\
\left(\begin{array}{c}1.3 \% \\
26\end{array}\right) \\
(34.7 \%) \\
9 \\
(12 \%) \\
5 \\
(6.7 \%) \\
4 \%) \\
(5.3 \%) \\
0\end{array}$ & $\begin{array}{c}54 \\
(52 \cdot 4 \%) \\
28 \\
(27 \cdot 2 \%) \\
9 \\
(8 \cdot 7 \%) \\
7 \\
(6 \cdot 8 \%) \\
3 \%) \\
(2.9 \%) \\
2 \% \\
(2 \cdot 0 \%)\end{array}$ & $\begin{array}{c}76 \\
(55.9 \%) \\
36 \\
(26.5 \%) \\
11 \\
(8.1 \%) \\
6 \%) \\
(4.4 \%) \\
6 \\
(4.4 \%) \\
1 \% \\
(0.7 \%)\end{array}$ & $\begin{array}{c}171 \\
(49.7) \\
101) \\
(29.4 \%) \\
31 \\
(9.0 \%) \\
20 \% \\
(5.8 \%) \\
16 \\
(4.6 \%) \\
5 \\
(1.5 \%)\end{array}$ \\
\hline Total & $\begin{array}{c}6 \\
(1.7 \%)\end{array}$ & $\begin{array}{c}24 \\
(7.0 \%)\end{array}$ & $\begin{array}{c}75 \\
(21 \cdot 8 \%)\end{array}$ & $\begin{array}{c}103 \\
(29.9 \%)\end{array}$ & $\begin{array}{c}136 \\
(39 \cdot 6 \%)\end{array}$ & 344 \\
\hline
\end{tabular}

$\mathbf{S}=$ Satisfactory $\mathbf{F}=$ Failure. $\mathrm{D}=$ Death. $\quad \mathrm{NT}=$ Not traced. $\mathrm{NA}=$ Not attempted. $U=\dot{U}$ ncertain.

Table I shows, as would be expected, an increasing failure rate with age. The high proportion of successes in the oldest group is probably not significant, owing to the small numbers involved, except to show that age itself is no bar to successful rehabilitation. The oddest patient to be treated was a woman born in 1860 who had had the right leg amputated above the knee when she was 5 years old but had never worn a prosthesis. To this extent she was perhaps not strictly a primary case, as she had not recently had a debilitating illness or undergone major surgery. She has been included, however, on the ground that it was her first attempt with a prosthesis. She was fitted with a pylon in November, 1948, and with an articulated prosthesis seven months later. She made uninterrupted progress despite domestic difficulties, and when last seen in September, 1951, she was "making better use of her leg than many half her age." At the other end of the scale six of the youngest patients were so debilitated that limb-fitting was not attempted, and over $25 \%$ have failed to learn to manage a prosthesis. The oldest double-thigh amputee to make successful use of prostheses was 81 . 
The incidence of failure has been higher in females. Table II shows the relative figures. There were approximately twice as many males as females in the series.

TABLE II.-Results in Relation to Sex Distribution

\begin{tabular}{|c|c|c|c|c|c|c|c|}
\hline & $\mathbf{S}$ & $\mathbf{F}$ & D & NT & NA & $\mathbf{U}$ & Total \\
\hline $\begin{array}{l}\text { Male .. } \\
\text { Fomale }\end{array}$ & $\begin{array}{c}119 \\
(52 \cdot 1 \%) \\
52 \\
(44 \cdot 8 \%)\end{array}$ & $\begin{array}{c}55 \\
(24 \cdot 2 \%) \\
46 \\
(39 \cdot 7 \%)\end{array}$ & $\begin{array}{c}24 \\
(10.5 \%) \\
7 \\
(6.0 \%)\end{array}$ & $\begin{array}{c}13 \\
(5.7 \%) \\
7 \\
(6.0 \%)\end{array}$ & $\begin{array}{c}12 \\
(5 \cdot 3 \%) \\
4 \\
(3 \cdot 5 \%)\end{array}$ & $\begin{array}{c}5 \\
(2 \cdot 2 \%) \\
0\end{array}$ & $\begin{array}{l}228 \\
116\end{array}$ \\
\hline
\end{tabular}

The death rate was appreciably higher amongst the males. It may be that they approached their rehabilitation with greater determination to overcome their disablement, in many cases possibly through a feeling of economic compulsion, which could explain the higher success rate at the cost of shortening life in some of them. The numbers are not large enough for us to draw more than tentative deductions on this score, particularly as the death rate in general in this age group is higher in males.

TABLE III.-Site of Amputation

\begin{tabular}{|c|c|c|c|c|c|c|c|c|}
\hline & $\begin{array}{l}\text { Single } \\
\text { A. K. }\end{array}$ & $\begin{array}{l}\text { Single } \\
\text { Thro. } \\
\text { K. }\end{array}$ & $\begin{array}{l}\text { Single } \\
\text { B.K. }\end{array}$ & $\begin{array}{c}\text { Double } \\
\text { A.K. }\end{array}$ & $\begin{array}{l}\text { One } \\
\text { A.K. } \\
\text { One } \\
\text { B.K. }\end{array}$ & $\begin{array}{l}\text { Double } \\
\text { B.K. }\end{array}$ & $\begin{array}{l}\text { Upper } \\
\text { Limb }\end{array}$ & Total \\
\hline s $\quad$. & $\begin{array}{c}118 \\
(49.4 \%)\end{array}$ & $\begin{array}{c}5 \\
(62.5 \%)\end{array}$ & $\begin{array}{c}26 \\
(57.8 \%) \\
0\end{array}$ & $\begin{array}{c}14 \\
(36.8 \%)\end{array}$ & $\begin{array}{c}3 \\
(33.3 \%\end{array}$ & $\begin{array}{c}3 \\
(100 \%)\end{array}$ & $(100 \%)$ & 17 \\
\hline $\begin{array}{ll}F & . \\
\text { D } & . .\end{array}$ & $\left.\begin{array}{c}(30.5 \% \\
21\end{array}\right)$ & $(25 \%)$ & $(20 \%)$ & $(42 \cdot 1 \%)$ & $(11 \cdot 1 \%)$ & 0 & 0 & 31 \\
\hline NT.. & $\begin{array}{c}(8 \cdot 8 \%) \\
11\end{array}$ & 0 & $(11 \cdot 1 \%)$ & $(7 \cdot 9 \%)$ & $(22 \cdot 2 \%)$ & 0 & 0 & 20 \\
\hline NA & $\begin{array}{l}(4.6 \%) \\
12\end{array}$ & 0 & 10 & $(7 \cdot 9 \%)$ & $\left.\begin{array}{c}(11 \cdot 1 \%) \\
2\end{array}\right)$ & 0 & 0 & 16 \\
\hline U .. & $\begin{array}{l}(3.0 \%) \\
4 \\
(1.7 \%)\end{array}$ & $(12.5 \%)$ & 0 & $3 \%$ & {$\left[\begin{array}{r}22.2 \\
0\end{array}\right.$} & 0 & 0 & 5 \\
\hline Total & 239 & 8 & 45 & 38 & 9 & 3 & 2 & \\
\hline
\end{tabular}

The preservation of the knee-joint is, of course, normally an advantage. However, the low success rate among those who have suffered double amputation-one above and one below the knee-the high death rate, and the high proportion for whom limb-fitting could be attempted (Table III), support the apparently paradoxical view held by me that in patients of this age rehabilitation, at least to a measure of independence, has been more readily effected among those who have had a double amputation at or above the knee. This is in direct relationship with the technique employed in the latter case, because initial rehabilitation is undertaken on short pylons, on which the patient is kept as near the ground as is permitted by the longer of the two stumps, and effort is minimized. A recent development of this technique, not included in this series, is the addition of rocker bases to the short pylon, which further reduce the expenditure of effort. The results of this method are most promising but it would be premature to give figures at this stage. (Note: The supply and use of short pylons has been regarded as a successful outcome in the double above-knee cases, although only five of them progressed to full-length articulated limbs within the period of review.)

\section{Disarticulation at the Knee}

Although the numbers are small, it is interesting to note the high success rate of disarticulation at the knee. (This includes two Stokes-Gritti amputations, of which one failed.) The success of these cases tends to confirm the impression gained that such patients learn to walk more readily and gain balance and confidence more quickly than those with the conventional above-knee amputation. This is probably because, with a disarticulation at the knee, endbearing can often be tolerated, thus permitting the axis of the body weight to be borne through the femur instead of through the ischium, and requiring less readjustment. It is necessary to provide a somewhat more cumbersome prosthesis for the disarticulation case owing to the bulbous extremity of the stump, and it is probable that the gait can never be so good as that obtained with the prosthesis designed for the ideal stump, but it is felt that for the elderly these disadvantages are outweighed by the relative ease of the early rehabilitation and, above all, by the fact that such an operation is the simplest one and is attended by the minimum of shock.

In only one of the cases (the one classified as uncertain) was there any breakdown of the stump, and it would seem that disarticulation could be adopted with advantage for many more patients in the age group under consideration. The Stokes-Gritti stump has never proved very satisfactory among ex-Service men from the limb-fitting point of view; end-bearing is seldom tolerated, and the terminal soft tissues are prone to circulatory deficiency, possibly owing to the fact that the flaps may have been taken too high to obtain advantage of the anastomosis round the knee. There seems no reason to expect better results in the higher age group than in the younger patients we have seen in the past, and the bone section involved would cause the very surgical shock which one wishes to avoid. We therefore do not see any place for the Stokes-Gritti amputation or any other modification of the classical disarticulation at the knee for the elderly patient.

\section{Cause of Amputation}

The most significant fact, as shown in Table IV, is that diabetics have relatively poor prognosis with regard to both rehabilitation and survival. As might be expected, in the

TABLE IV.-Cause of Amputation

\begin{tabular}{|c|c|c|c|c|c|c|c|}
\hline & $\mathbf{S}$ & $\mathbf{F}$ & D & NT & NA & $\mathbf{U}$ & Total \\
\hline $\begin{array}{l}\text { Diabetes } \\
\text { Embolism }\end{array}$ & $\begin{array}{c}20 \\
(34 \cdot 5 \%) \\
0\end{array}$ & $\begin{array}{c}22 \\
(38.0 \%) \\
1\end{array}$ & $(15 \cdot 5 \%$ & $\begin{array}{c}4 \\
(6.9 \%) \\
0\end{array}$ & $\begin{array}{c}3 \\
(5 \cdot 1 \%) \\
0\end{array}$ & $\begin{array}{l}0 \\
0\end{array}$ & 58 \\
\hline Thrombosis .. & & $(5$ & $(50 \%)$ & 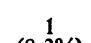 & 1 & 10 & 12 \\
\hline $\begin{array}{l}\text { Raynaud's dis- } \\
\text { ease }\end{array}$ & $\begin{array}{l}(30.3 \%) \\
2 \% \\
(100 \%)\end{array}$ & (33.) & $\begin{array}{l}(8.5 \%) \\
0\end{array}$ & 0 & б) & $(8,5)$ & 2 \\
\hline $\begin{array}{l}\text { Other forms of } \\
\text { gangrene } \\
\text { Ulceration }\end{array}$ & $\begin{array}{l}90 \\
(50.6 \%) \\
24\end{array}$ & $\begin{array}{c}55 \\
(30.9 \%) \\
8\end{array}$ & $\begin{array}{c}12 \\
(6 \cdot 7 \%) \\
2\end{array}$ & $\begin{array}{l}11 \\
(6 \cdot 2 \%) \\
1\end{array}$ & $\begin{array}{l}8 \\
(4.5 \%) \\
2\end{array}$ & $(1.2 \%)$ & $\begin{array}{r}178 \\
39\end{array}$ \\
\hline Neoplasm & $\begin{array}{l}10 \% \\
(55.6 \%)\end{array}$ & 4 & $\begin{array}{r}(3.1 \%) \\
422.2 \%)\end{array}$ & 0 & 0 & 0 & 18 \\
\hline Trauma & $11^{10}$ & $\begin{array}{l}3 \\
30 \\
\left(16.7^{\circ}\right)\end{array}$ & $\begin{array}{l}1 \\
(5.6 \%)\end{array}$ & $\left(11^{2} \%\right.$ & $(5.6 \%)$ & $\mathbf{0}$ & 18 \\
\hline $\begin{array}{l}\text { Pyogenic infec- } \\
\text { tion }\end{array}$ & $(75 \%)$ & $(12 \cdot 5 \%)$ & 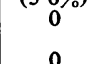 & $(12 \cdot 5 \%)$ & 0 & 0 & 8 \\
\hline Aneurysm $\quad \ldots$ & $\begin{array}{c}(33 \cdot 3 \%) \\
2\end{array}$ & $\begin{array}{c}(66.7 \%) \\
0\end{array}$ & 1 & $\mathbf{0}$ & 1 & $\mathbf{0}$ & 4 \\
\hline Elephantiasis. . & $\begin{array}{c}1 \\
(50 \%)\end{array}$ & $\begin{array}{l}1 \\
(50 \%)\end{array}$ & 0 & 0 & 0 & $\mathbf{0}$ & 2 \\
\hline Tota & 171 & 101 & 31 & 20 & 16 & 5 & 344 \\
\hline
\end{tabular}

acute pyogenic and traumatic groups the success rate is high. This is probably because they have not suffered from prolonged debilitating illness. The presence or absence of concomitant disease or disablement is of more direct prognostic significanee.

\section{Complications}

The complications (Table V) were in the main cardiovascular and respiratory, and disorders of locomotion. The latter include disabilities of the upper limbs, owing to the fact that these patients have at least to learn to walk as quadrupeds. Specific complications, together with numbers of cases exhibiting each complication, are shown in

TABLE V.-Complications

\begin{tabular}{|c|c|c|c|c|c|c|c|}
\hline & $\mathbf{S}$ & $\mathbf{F}$ & D & NT & NA & $\mathbf{U}$ & Tots \\
\hline $\begin{array}{l}\text { Complications } \\
\text { present } \\
\text { Complications } \\
\text { absent }\end{array}$ & $\begin{array}{c}81 \\
(40 \cdot 1 \%) \\
90 \% \\
(63 \cdot 4 \%)\end{array}$ & $\begin{array}{c}66 \\
(32 \cdot 7 \%) \\
35 \% \\
(24 \cdot 7 \%)\end{array}$ & $\begin{array}{c}20 \\
(9.9 \%) \\
11 \\
(7.7 \%)\end{array}$ & $\begin{array}{c}14 \\
(6.9 \%) \\
6\end{array}$ & $\begin{array}{c}16 \\
(7.9 \%) \\
0\end{array}$ & $\begin{array}{c}5 \\
(2.5 \%) \\
0\end{array}$ & \\
\hline
\end{tabular}


Table VI. It will be appreciated that two or more complications may have been coexistent in individual cases. The figures emphasize the importance of defects of the contralateral leg, the arms, vision, heart disease, and deafness.

TABLE VI.-Specific Complications

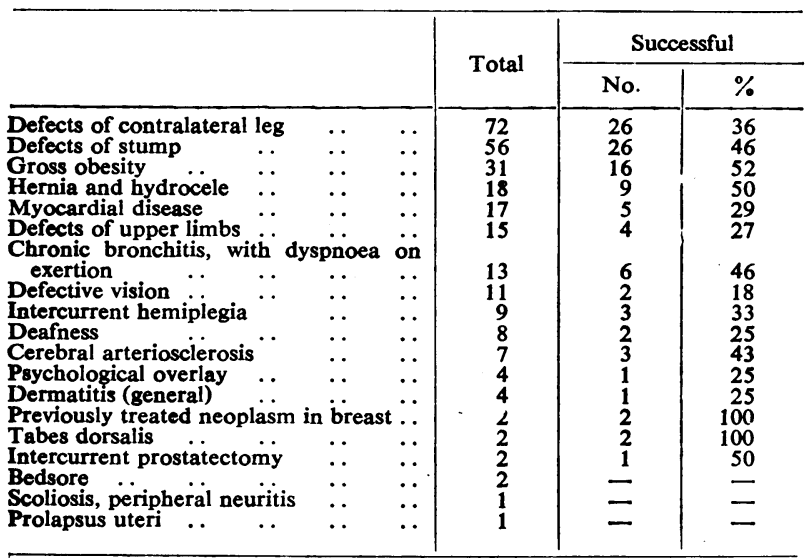

The last of these is interesting, and its inclusion among the complications is probably explained by the fact that the deaf person retires into himself and is difficult to bring into group therapy and into the atmosphere of optimism one can cultivate in his more fortunate fellows. Obesity has been less of a handicap than might have been expected.

\section{Discussion}

The results in these cases show that no single complication encountered can be regarded as an absolute contraindication to limb-fitting. On the other hand, one cannot simply regard the elderly amputee as having a stump for which all that is required is to fit a prosthesis to enable him to walk. On the contrary, the stump is by no means the most important part of the problem. A comprehensive examination must be made of the patient's entire physical and mental make-up, and suitable treatment of any concomitant disability instituted in conjunction with prosthetic rehabilitation.

The complicating factors are, in fact, wider even than this. The environment to which the patient returns on discharge is of vital importance. We not infrequently see patients who have made good progress and who are discharged from the walking school able to control their prosthesis and to look after themselves fairly well. Yet when we see them on follow-up we find they have hardly worn the prosthesis, and the musculature has lost tone to the extent that they can no longer control it. Inquiry reveals that they live alone, perhaps in an upstairs flat, or it may be that they have simply lacked the incentive to make the effort to persevere. It would seem that here is a problem of welfare which is outside the scope of the Limb Service, and falls more within the province of the social medicine specialist.

Again, we have had to contend with patients who have acquired an unwarranted optimism concerning what can be done for them. They expect to be provided with a prosthesis with which they can walk immediately and without effort. They may be in poor physical condition, and often their stumps may be flabby, neglected, and quite unprepared for wearing a prosthesis. It is impossible to convince some of them that they will not be able to manage a prosthesis other than by letting them try for themselves on a pylon. The effect on morale of the inevitable failure can be imagined. We have known of patients admitting that they had been prevailed upon to accept amputation by the promise of easy function with a prosthesis. The psychological approach from the limb surgeon's point of view is much simplified if a more conservative briefing has been given in the general hospital and the patient has been warned beforehand that he will have a prolonged and strenuous programme before him, but that if he will make the effort he should be able to walk. This programme should be initiated from an early date and maintained throughout by a regime of active physiotherapy, directed not only to the stump but to the whole bodily musculature, together with occupational and diversional therapy suited to the intellectual standard of the individual. The programme can with advantage be phased, each phase having a target which must be attained before the next phase is started (Marjory Warren, 1950, personal communication). This may seem a counsel of perfection unrelated to the pressure on hospital beds in these days, but it is my belief that there would actually be a saving of time, and therefore of beds, if such a programme were in uniform use.

The following brief case histories illustrate some of the points raised.

Case 66.-A married woman aged 68. Double above-knee amputation, the later amputation being performed on December 22 , 1948, for gangrene of unspecified nature. She was grossly overweight. W.R. positive; prior to the amputation she had been diagnosed as tabetic. She made uninterrupted progress on short pylons, and, although she did not progress to full-length articulated limbs, she obtained enough function from the short pylons for the result to be regarded as an unqualified success.

Case 69.-A man aged 81. Amputation of right thigh through lesser trochanter following road accident. There was an unreduced congenital dislocation of the left hip. He lives by himself. He learned to manage a "through hip" (tilting table) prosthesis without difficulty, and in spite of his unfavourable home circumstances continued to make good use of it.

Case 223.-A married woman aged 66. Left above-knee amputation as a result of old-standing osteomyelitis. She had generalized seborrhoeic dermatitis, was deaf, and had defective vision $(6 / 60 \mathrm{R}$. and L.). Despite this, she did well on a pylon and also learned to manage an articulated prosthesis competently. Four months later she was found to have given up the effort and had reverted to a wheelchair existence.

Case 251.-A man aged 69. Right above-knee and left belowknee amputation. Despite his excessive weight he made an uninterrupted and rapid rehabilitation, which was maintained.

The cause of death in the 31 patients who died during or immediately following limb-fitting procedures was as follows: coronary occlusion, six ; hypertensive myocardial failure, four ; diabetic coma, three ; pneumonia, hemiplegia, and secondary carcinomatosis, two each; renal failure in association with diabetes, diabetic gangrene of contralateral leg, senile gangrene of contralateral leg, dissecting aneurysm with renal suppression, and perforated gastric ulcer, one each. In seven cases the cause of death could not be ascertained. Only one death occurred while the patient was actually undergoing fitting of the prosthesis or training in walking; this patient collapsed and died of acute cardiac dilatation in the walking school. $\mathrm{He}$ was a hypertensive subject.

In consideration of the fact that all cases in the series were under observation for upwards of a year, the death rate gives no cause for alarm or for modification of policy. It is very doubtful if the effort of limb-fitting had any material effect in shortening life, and, even if it did, the majority of patients would prefer to make the attempt rather than pass the rest of their life in a chair. The manifestly bad risks were not attempted.

\section{Summary}

A series of 341 consecutive primary amputees of 65 years or more who have been referred to Roehampton Limb Fitting Centre for a prosthesis has been reviewed.

The results suggest that no single factor will determine the selection of patients suitable for limb fitting, and that an assessment must be made of the entire physical and mental make-up. Age itself is not an adverse factor, and there is no evidence that wearing a prosthetic limb has shortened life significantly. 
It is suggested that correct briefing and an energetic and continued physical programme are of inestimable value in preparing patients for wearing a prosthesis.

The subsequent care of the elderly amputee after training in the use of the prosthesis is a problem in social medicine as yet not adequately met.

I am indebted to the Director-General of Medical Services, Ministry of Pensions, for permission to publish this paper. My thanks are also due to Dr. R. Langdale Kelham for advice and help in preparing the text, and to the staff of Roehampton Limb Fitting Centre, in particular to $\mathrm{Mr}$. D. Congalton, senior walking instructor, without whose enthusiasm and untiring efforts many of these patients would never have walked.

\section{ReFERENCES}

Ministry of Pensions (1951). Rehabilitation Following Amputation. Publi-

Scales, J. T. (1950). J. Bone Jt Surg., 32B, 60 ; and personal communication.

\section{ORDER OF ST. JOHN OF JERUSALEM}

The London Gazette has announced the following promotions in, and appointments to, the Venerable Order of the Hospital of St. John of Jerusalem:

As Knights: Sir Horace Evans, K.C.V.O., M.D., F.R.C.P., Major-General F. A. Maguire, C.M.G., D.S.O., V.D., M.D. F.R.C.S., Brigadier R. M. Gorssline, D.S.O., M.B., LieutenantColonel E. A. H. Russell, O.B.E., V.D., M.B., Mr. A. Wai Tak Woo, M.B., F.R.C.S., Drs. G. B. Peat and C. A. Verco. As Dame: Mrs. Katie Ardill-Brice, O.B.E., M.B. As Commanders (Brothers): Colonel T. E. Holland, M.D., Drs. Tseung Fat in, E. H. Lodge, K. C. McGibbon, H. R. Mustard, and W. P Warner, C.B.E., D.S.C. As Associate Commander (Brother): Dr. K. Budeiri. As Commander (Sister): Dr. Ella P. Hopgood. As Officers (Brothers): Surgeon Rear-Admiral F. H. Nimmo, Brigadier C. W. Nye, O.B.E., E.D., M.B., Colonel W. A. Jones, O.B.E., V.D., M.D., Colonel J. E. Snow, R.A.M.C., LieutenantColonel S. H. Heard, M.B.E., M.R.C.S., L.R.C.P., Major A. S Lewis, M.D., F.R.C.S., Messrs. D. P. McIntyre, F.R.C.S., H. H Barnett, M.B., F.R.C.S., A. Perry, O.B.E., M.B., F.R.C.S., C. D Gossage, O.B.E., M.D., F.R.C.S., W. H. C. Romanis, M.C. M.B., F.R.C.S., Drs. J. K. Thomas, J. Brown, T. P. Eddy, L. G Blaze, C. H. Drake, G. W. J. Bousfield, P. P. Lynch, W. G. Rich R. J. Brown, G. D. W. Cameron, E. Dwyer, H. J. Ferrier, J. L. R. Gendron, H. D. Hebb, J. H. A. Paquette, W. S. Stanbury, M.B.E. H. H. C. Fuller, L. M. Comissiong, E. R. B. Murray, G. K Thornton, J. Prentice, R. McE. Paterson, N. L. Birkett, J. J. du Pre Le Roux, R. S. Steel, H. H. Hurst, and T. C. James. As Officers (Sisters): Mrs. Ellen W. M. Shaw, M.R.C.S., L.R.C.P., and Miss Olive S. May, M.R.C.S., L.R.C.P. As Serving Brothers: Surgeon Captain E. H. Lee, Captain A. F. McDonald, M.B., Messrs. M. Backwell, M.B., F.R.C.S., D. R. Jennings, M.B., F.R.C.S., Drs. R. G. Sprenger, I. B. McRae, Chang Hoey Chan, C. L. Tessensohn, V. P. Robinson, R. N. Curnow, J. A. Sacco. R. H. Blackburn, W. Isbister, A. Barlow, J. Crook, E. MacD. Fogo, J. A. Mackay, J. J. MacRitchie, A. L. Peers, N. R. Rawson, O.B.E., R. R. Strong, Ll. H. Werden, T. H. N. Whitehurst, O.B.E., E. B. Figueiredo, D. P. K. Jockel, T. K. Abbott, L. W. Fitzmaurice, O.B.E., R. D. K. Levy, P. D. A. Fowler, H. W. Needham, E. T. Meyer, J. D. Allen, C. D. Bateman, R Swinburn, V. C. Dyring, N. J. Caldwell, and F. W. R. Lukin As Associate Serving Brothers: Drs. A. J. Thumboo, E. B. Israel, R. A. Trope, S. Etzine, and H. Kaye. As Serving Sisters: Drs Sophia M. R. Thomson, Margaret Owens, Winifred I. Robertson, and Marguerite C. MacDonald.

The benefits of a chiropody service to old people are emphasized by Dr. H. J. Rae in the Health Bulletin (January, 1953) of the Department of Health for Scotland. For some time the service has been provided for the residents of old people's homes belonging to the Aberdeen Corporation, and other local authorities in Scotland have made similar provision. More recently the scheme has been extended to cover old people in their own homes in Aberdeen. The service is not free, since experience has shown that chiropody treatment given free at out-patient clinics was grossly abused. A charge of $4 \mathrm{~s}$. per visit is therefore made, but it may be remitted in whole or in part if circumstances so require.

\section{Nova et Vetera}

\section{DR. JAMES GREGORY \\ NEW LETTER FOUND}

James Gregory, who was born in January, 1753, is remembered to-day only through the powder which bears his name, although in his lifetime he was a most striking figure in the Edinburgh School of Medicine. He graduated M.D. at Edinburgh in 1774 and then spent some time under Gaubius at Leyden. His father, John Gregory (1724-73), occupied the chair of practice of medicine at Edinburgh from 1766 until his death. For 20 years previously Robert Whytt, professor of the institutes of medicine, had been the actual professor of the practice of medicine, and in $\mathbf{1 7 6 9}$ his successor, Willi a m Cullen, petitioned the authorities to appoint him and John Gregory joint professors of medicine, so that each should teach in alternate sessions the theory and the practice of medicine. When John died, James Gregory was still a student. $\mathrm{Cu} 11$ e n continued as professor of practice of medicine, and the chair thus made

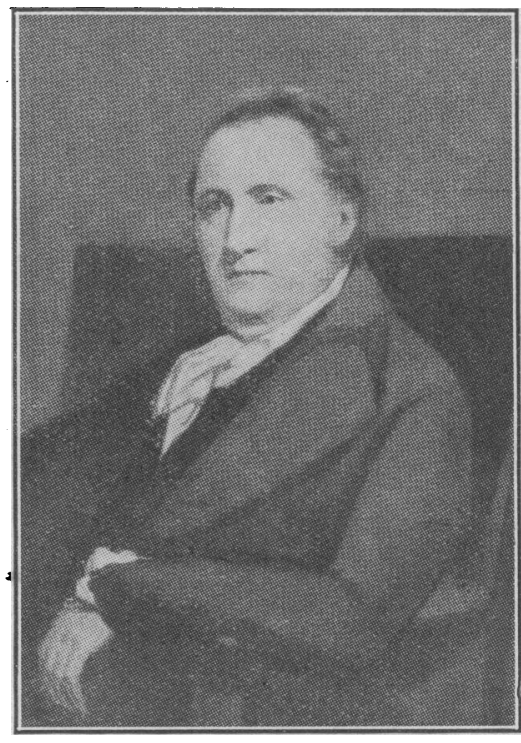
vacant was not

filled until June 19, 1776, when James was elected professor of the institutes of medicine, becoming the fifth member of the Gregory family to occupy a professorial chair at Edinburgh. Soon afterwards he published his textbook, Conspectus Medicinae Theoreticae ad Usum Academicum. In 1792 he succeeded Cullen to the chair of practice of medicine. He was an accomplished Latin scholar, a great physician, and a brilliant and witty lecturer. His teaching enhanced the reputation' of the Edinburgh school over a long period, and his reputation was second only to that of Cullen. He published a set of literary and philosophical essays in 1792. Gregory was a friend of Robert Burns, and Raeburn painted his portrait in 1798 ; a part of it is reproduced here.* He died in 1821 .

\section{Obviating Costiveness}

A letter, reproduced below, written by Gregory to an unknown correspondent has recently been brought to light, and the bicentenary of Gregory's birth is an appropriate occasion for its publication. The letter was discovered among papers in the possession of Captain Sir James Paget, Bt., R.N., of Ballater, a grandson of Sir James Paget, the distinguished surgeon, and it has been presented to the British Medical Association.

St. Andrew's Square

Sir, Wed: Night 22 Jan: 1817

Inclosed I send you a Receipt for the same kind of Laxative Pills, which by Dr. Macfarlane's advice you have been using of

*The illustration is taken from the reproduction of the Raeburn portrait of Dr. James Gregory in History of Scottish Medicine by John D. Comrie, 2nd edition, vol. 2, 1932, by kind permission of the publishers, the Wellcome Historical Medical Museum. The original is in the possession of Sir Ian Forbes-Leith, Bt. 